\title{
Discovery Teaching about Plane Geometric Extreme Problems with the Help of Geogebra Software at Secondary School in Vietnam
}

\author{
Ngoc-Giang Nguyen ${ }^{1, *}$, Thi-Ngoc Hoang ${ }^{2}$, Thi-Khanh-Linh Bui ${ }^{3}$ \\ ${ }^{1}$ Banking University of Ho Chi Minh City, 36 Ton That Dam, Nguyen Thai Binh Ward, District 1, Ho Chi Minh City, Vietnam \\ ${ }^{2}$ Vietnam Australia Primary School, Secondary School and High School, 10 Mai Chi Tho, Thu Thiem Urban Area, District 2, Vietnam \\ ${ }^{3}$ Mach Kiem Hung Secondary School, 15 / 1D Ngo Quyen, Ward 10, District 5, Ho Chi Minh City, Vietnam
}

Received March 29, 2021; Revised May 8, 2021; Accepted June 5, 2021

\section{Cite This Paper in the following Citation Styles}

(a): [1] Ngoc-Giang Nguyen, Thi-Ngoc Hoang, Thi-Khanh-Linh Bui, "Discovery Teaching about Plane Geometric Extreme Problems with the Help of Geogebra Software at Secondary School in Vietnam," Universal Journal of Educational Research, Vol. 9, No. 6, pp. 1340-1352, 2021. DOI: 10.13189/ujer.2021.090624.

(b): Ngoc-Giang Nguyen, Thi-Ngoc Hoang, Thi-Khanh-Linh Bui (2021). Discovery Teaching about Plane Geometric Extreme Problems with the Help of Geogebra Software at Secondary School in Vietnam. Universal Journal of Educational Research, 9(6), 1340-1352. DOI: 10.13189/ujer.2021.090624.

Copyright $\mathrm{C} 2021$ by authors, all rights reserved. Authors agree that this article remains permanently open access under the terms of the Creative Commons Attribution License 4.0 International License

\begin{abstract}
Discovery teaching is an active teaching method. It helps develop the quality of student's competencies. It is really important in teaching using math tools and means. Our research focuses on understanding the perspective of discovery teaching as well as referring to the construction of a teaching method of plane geometry extreme problems with the help of specific GeoGebra software at secondary school. By the method of theoretical research, investigation as well as descriptive statistical methods, we find that using GeoGebra software has a great impact on the learning of plane geometric extreme problems of students. Students are interested and active in lesson construction. Students examine, create new problems by themselves, verify and discover solutions. The study also shows that GeoGebra software helps predict and find solutions, especially plane geometric extreme problems with a one-variable function. In Vietnam, with the introduction of a new general education program in mathematics, the application of mathematical tools and means is now very important. GeoGebra software was introduced right in 6th grade to teach. Students were introduced in detail to the features of the software. Therefore, the research results have an important meaning in building a lesson in solving plane geometric extreme problems with the help of GeoGebra softwarec at secondary school. Our paper refers to the views of
\end{abstract}

discovery teaching, the teaching process using GeoGebra software in plane geometric extreme problems and gives an example of discovery teaching that applies GeoGebra software in plane geometric extreme problems.

Keywords Discovery Teaching, Extreme Problems, Geogebra Software, Strong Points, Restrictions

\section{Introduction}

Discovery teaching is a teaching method that promotes student activeness. Some people consider discovery teaching as a method, but others consider discovery teaching as a viewpoint. Discovery teaching helps learners build their knowledge. Therefore, discovery teaching is a teaching method that helps learners greatly in forming and constructing knowledge. In discovery learning, students operate with or without the help of a teacher. Teachers act as companions, who build knowledge with students. In this teaching method, students will not feel confused or inferior, but confident. Students will not be afraid of making mistakes. Through their own mistakes, students will clearly understand the content and nature of the problem to be discovered. In the general mathematics program in 
Vietnam, plane geometric extreme problems play an important role. First, the plane geometry extreme problem is functional thinking in nature. That functional thinking is the core thinking of the mathematics. Second, the problems of plane geometry extreme are the problems showing the optimal nature. This is a topic that currently interests people in many professions, not just mathematics. In particular, in some emerging fields such as artificial intelligence, the optimization problem is a problem studied by many people. Third, the plane geometric extreme problems are very good materials that show interdisciplinary integration between different subjects. Fourth, the plane geometric extreme problems are content that can be applied to dynamic geometry software or mathematics, such as GeoGebra software. From the above features, the article will focus on answering three questions in the article:

1. What are the views of discovery teaching?

2. How does the teaching process using GeoGebra software in plane geometric extreme problems?

3. How do we give an example of discovery teaching that applies GeoGebra software in plane geometric extreme problems?

\section{Materials and Methods}

\subsection{Perspectives on Discovery Teaching}

Discovery teaching is a type of teaching in which learners build their knowledge through experimentation and draw rules from the results of these experiments. The purpose of the discovery teaching method is that learners build their own knowledge. From there, learners will gain knowledge and competencies at a higher level than traditional teaching. [1] Discovery teaching is a form of teaching that provides students with opportunities to experiment and analyze to find new concepts, new properties, and to help students master knowledge as well as practice steps, and discovery teaching methods also create opportunities to form social skills, teamwork. [2] Discovery teaching is a teaching method that adjusts teaching in such a way that learners acquire knowledge that they have not previously learned, or only partially learned.
In discovery teaching, knowledge is designed so that students can find concepts and rules through how to ask questions and answer them. When exploring concepts and properties, students observe, classify, guess, explain, draw conclusions, and so on, to find out some essence or general rules. [3] Discovery teaching is designed into activities that engage students more in learning. Instead of being passive learners receiving large amounts of unrelated, discrete information, students are asked to make their connections between what they are learning and what they have been through in real life. Students must move from the concept of knowledge that should be imparted directly from the teacher to the concept that students must actively seek and dominate through activities. Discovery teaching encourages learners' cognitive changes. It is a version of real-world science like real scientists, not the science commonly used in textbooks. [4]

Discovery teaching is a form of teaching with high self-direction and constructivism. [5] Discovery teaching includes teaching paradigms and strategies that focus on positive, hands-on learning opportunities for students. [6] Discovery teaching is a teaching method in which teachers interact with students about problems. Teachers play the role of guiding students to discover concepts, properties and solve exercises by themselves. Teachers with available experience as well as critical thinking will comprehensively evaluate students' learning activities and connect teaching with real life. [7] Discovery teaching is a teaching method designed to engage students, under the guidance of a teacher, and through reading materials, they will gain insight into problems. [8] Discovery teaching is a teaching process in which students experience the practice of information discovery, to find new concepts or rules while helping students create new strategies or solutions. [9] Discovery teaching has many different perspectives. Through learning tasks, students are prompted, explained, and simulated to gain knowledge for themselves. [10] Discovery teaching is typical constructivist teaching, based on problem-solving activities related to the design and implementation of scientific experiments. Scientific discovery is often understood as the process of combining minds between theories proposed and evidence gathered by experiments. [11] 


\subsection{The Strong Points and Restrictions of Discovery Teaching}

Table 1. The strong points and restrictions of discovery teaching

\begin{tabular}{|l|l|}
\hline Advantages & Disadvantages \\
\hline $\begin{array}{l}\text { It improves learner processing abilities as well as enhances } \\
\text { learners' intellectual capacity; Discovery teaching helps learners } \\
\text { move from learning due to external pressure to self-interest; }\end{array}$ & $\begin{array}{l}\text { It depends on the teacher's exploratory questioning; Discovery } \\
\text { teaching is only really good if teachers develop strategies to } \\
\text { bring into play the full potential of their students. } \\
\text { as receiving and remembering information for longer. Students } \\
\text { have access to higher-order thinking, improving academic } \\
\text { achievement. }\end{array}$ \\
\hline $\begin{array}{l}\text { It focuses on the processes or structure of knowledge rather than } \\
\text { information knowledge; Learners will experience as well as } \\
\text { actively participate in the discovery, so they have a greater grasp } \\
\text { of teaching content than traditional teaching. }\end{array}$ & $\begin{array}{l}\text { Fiscovery teaching takes a lot of the teacher's time and effort. } \\
\text { population will make discovery learning less effective. Each } \\
\text { different object must have a different way of teaching and asking } \\
\text { questions. This makes teachers afraid to apply the discovery } \\
\text { teaching method in practice. }\end{array}$ \\
\hline $\begin{array}{l}\text { Teachers will gain a lot of new knowledge from organizing } \\
\text { discoveries for students. }\end{array}$ & $\begin{array}{l}\text { Teachers must be experienced to apply the method of discovery } \\
\text { teaching well in reality. Newly graduated teachers with little } \\
\text { experience will find it difficult to complete their teaching well } \\
\text { with this method. }\end{array}$ \\
\hline
\end{tabular}

[6], [12]

\subsection{Overview of GeoGebra Software}

GeoGebra software was invented by Markus Hohenwarte in 2001. [13] GeoGebra software is open-source software. [14] It is structured software. [15] GeoGebra software has a friendly interface, easy to use. [16] GeoGebra has many features to meet the needs of users of algebra and geometry. [17] Users can manipulate by drawing command buttons directly or by commands. GeoGebra can generate dynamic features that can be used with any Internet browser that supports Java on any operating system. [18] GeoGebra software allows inserting pictures and editing with Latex. [19] GeoGebra software provides multi-functionality that allows students to explore relationships between mathematical objects and their representational graphs. [20] The software has a huge user community from 190 countries around the world attracting 300,000 downloads per month. [21] This is the good software to help students understand the subject better. [22] GeoGebra software helps teachers to be flexible in teaching. Teachers are co-constructors of knowledge with students. Teaching facility GeoGebra places students at the center of the teaching process as well as develops students' thinking and skills. [23]

\subsection{Teaching Process Using GeoGebra Software in Plane Geometric Extreme Problems}

Through the study of documents on GeoGebra software by [18], [24-26] as well as problems on plane geometry. [16], [27-29], we propose the teaching process using the Soft GeoGebra is:

Step 1: Determine the Applicability of GeoGebra Software in the Plane Geometric Extreme Problems

From the facts of the problem, analyze and find out the relationship between the unknown and the known quantity. If this relationship is essentially an extreme problem of a one-variable function, we can say that we can apply GeoGebra software to help in solving the problem. Besides, if the problem is an arbitrary function in nature, we can use GeoGebra software to verify, create new problems, detect and correct mistakes, simulate and interact, etc.

\section{Step 2: Draw Figures on GeoGebra Software}

Students use basic buttons on GeoGebra software to draw figures of the problem given by the teacher. Students use the point, line, polygon, circle buttons, as well as the relationship and measurement buttons to draw figures in the GeoGebra software.

\section{Step 3: Determine the Properties and Relationships as Required by the Problem}

Students move shapes in different states and objects to discover hidden properties and relationships between objects ... Students through GeoGebra software see basic properties, explore new properties. Students base on the drawings and assumptions of the problem to determine the fixed factors, the changing factors ...; from there drag and move objects such as points, lines or change the measure of angles, observe the drawings on the same plane to find parallel, perpendicular relationships, ...

\section{Step 4: Solve the Math Problem}

Students rely on the detection of relational properties to provide a solution to the problem. Relying on the discovery of properties of plane geometry as well as new properties, from which students give the direction of logical reasoning and find better solutions to the problem. Students can find a variety of solutions. 


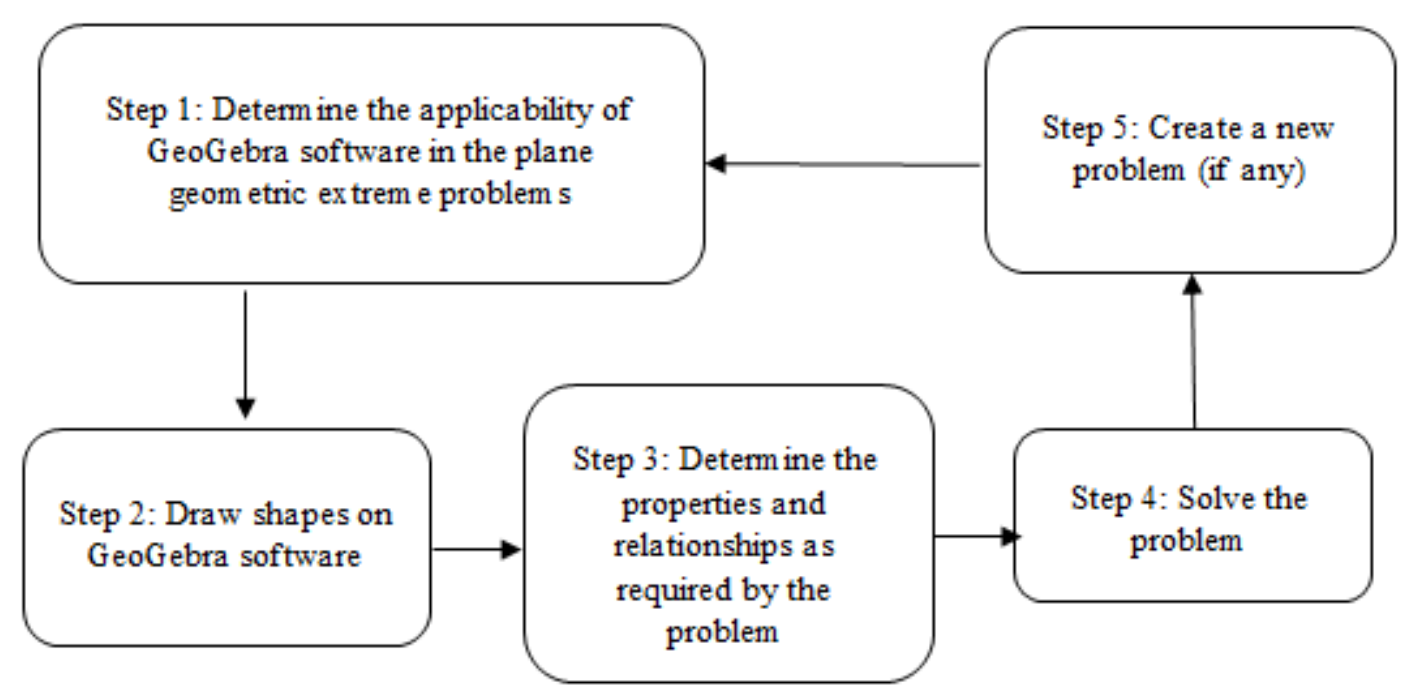

Figure 1. Teaching process with the help of GeoGebra software (Source: Personal collection)

\section{Step 5: Create New Problems (if any)}

By replacing the assumptions of the problem, moving the figure to discover new properties and new results, students will find new problems by themselves compared to themselves. Students move the objects and observe their changes as well as properties, relationships, and results. Students can discover new relationships, new properties, and change problems to create new problems based on the original problem.

\subsection{An Illustrative Example of Discovery Teaching Applying GeoGebra Software in Plane Geometric Extreme Problems}

\section{Example 1}

Given an acute triangle $A B C$ with the base side $B C=b$ and corresponding height $A D=a$. Find the dimensions of the rectangle so that the rectangle has the largest area possible and inscribed within the triangle, knowing that one side of the rectangle lies on the bottom edge as shown.

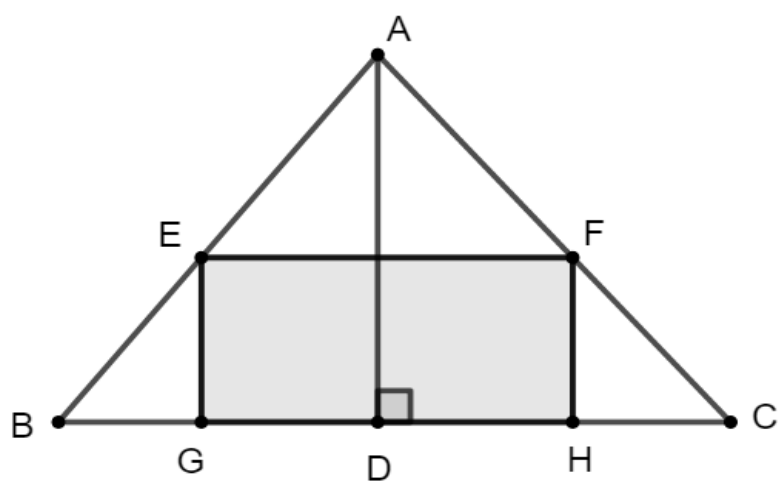

Figure 2. Extreme Problems (Source: Personal collection) 
Table 2. Teaching and learning activities of plane geometric extreme problems

\begin{tabular}{|c|c|c|}
\hline \multicolumn{2}{|c|}{ Teacher's activities } & Student activities \\
\hline \multicolumn{3}{|c|}{ Step 1: Determine the applicability of GeoGebra software in the plane geometric extreme problems } \\
\hline \multicolumn{2}{|c|}{$\begin{array}{l}\text { Suppose } E G=x, E F=y \text {. Express the area of a } \\
\text { rectangle EFHG in terms of } \mathrm{x} \text { and } \mathrm{y} \text {. }\end{array}$} & $\begin{array}{l}\text { Suppose } E G=x, E F=y \\
\text { The area of a rectangle EFHG is } \mathrm{xy} .\end{array}$ \\
\hline \multicolumn{2}{|c|}{$\begin{array}{l}\text { Please represent the area of a rectangle EFHG in the } \\
\text { variable } \mathrm{x} \text {. }\end{array}$} & $\begin{array}{l}\text { Since } \triangle A E F " \triangle A B C, \text { so } \frac{y}{b}=\frac{a-x}{a} \Rightarrow y=\frac{b}{a}(a-x) \\
\text { Hence, } x y=\frac{b}{a}(a-x) x\end{array}$ \\
\hline \multicolumn{2}{|c|}{$\begin{array}{l}\text { Then, of which function does the problem ask to find the } \\
\text { smallest value and how many variables are there? Is it } \\
\text { possible to use GeoGebra software to help with solving } \\
\text { the math problem? }\end{array}$} & $\begin{array}{l}\text { The problem requires finding the minimum value of the function } \\
f(x)=\frac{b}{a}(a-x) x \text { which is the extreme value of a one-variable function, and } \\
\text { GeoGebra software can be used to assist in solving the problem. }\end{array}$ \\
\hline \multicolumn{3}{|c|}{ Step 2: Draw figures on GeoGebra software } \\
\hline \multicolumn{2}{|c|}{$\begin{array}{l}\text { Use GeoGebra software to draw figures with the } \\
\text { following steps: }\end{array}$} & Students follow and perform \\
\hline $\begin{array}{l}\text { Numerical } \\
\text { order }\end{array}$ & Shapes & Steps \\
\hline 1 & $\begin{array}{l}A=(4,6) \\
\text { Input... }\end{array}$ & Enter the command $\mathrm{A}=(4,6)$ in the box "Input". \\
\hline 2 & $\begin{array}{l}\mathrm{B}=(2,2) \\
\text { Input... }\end{array}$ & Enter the command $B=(2,2)$ in the box "Input". \\
\hline 3 & $\begin{array}{l}\mathrm{C}=(8,2) \\
\text { Input... }\end{array}$ & Enter the command $C=(8,2)$ in the box "Input". \\
\hline 4 & Segment & $\begin{array}{l}\text { - Select the shape Segment } \\
\text { - Then, choose } 2 \text { points } A, B \\
\text { - Then, choose } 2 \text { points } A, C \\
\text { - Then, choose } 2 \text { points } B, C\end{array}$ \\
\hline 5 & f Perpendicular Line & $\begin{array}{l}\text { - Select the shape Perpendicular Line } \\
\text { - Then, select the line } B C \text { and point } A \text { to draw the line perpendicular to } B C \text { at point } \\
A\end{array}$ \\
\hline 6 & Intersect & $\begin{array}{l}\text { - Select the shape Intersect } \\
\text { - Then, select the line } B C \text { and the line perpendicular to } B C \text { at point } A \text { to create } \\
\text { intersection } D\end{array}$ \\
\hline 7 & Segment & $\begin{array}{l}\text { - Select the shape Segment } \\
\text { - Then, choose } 2 \text { points } A, D\end{array}$ \\
\hline 8 & Point on Object & $\begin{array}{l}\text { - Select the shape Point on Object } \\
\text { - Get point } E \text { of line } A B \text {. }\end{array}$ \\
\hline 9 & Intersect & $\begin{array}{l}\text { - Select the shape Intersect } \\
\text { - Then, select segment } B C \text { and line } \\
\text { perpendicular to } B C \\
\text { - Right-click at the intersection and rename it to } G\end{array}$ \\
\hline 10 & Segment & $\begin{array}{l}\text { - Select the shape Segment } \\
\text { - Then, choose } 2 \text { points } G, E\end{array}$ \\
\hline 11 & Perpendicular Line & $\begin{array}{l}\text { - Select the shape Perpendicular Line } \\
\text { - Then, select the line } G E \text { and point } E \text { to draw a line perpendicular to } G E \text { at point } E\end{array}$ \\
\hline
\end{tabular}


Table 2 Continued

\begin{tabular}{|c|c|c|}
\hline 12 & Intersect & $\begin{array}{l}\text { - Select the shape Intersect } \\
\text { - Then, select segment } A C \text { and line } \\
\text { perpendicular to } G E \text { at point } E \text { to create intersection } F\end{array}$ \\
\hline 13 & Perpendicular Line & $\begin{array}{l}\text { - Select the shape Perpendicular Line } \\
\text { - Then, select the line } E F \text { and point } F \text { to draw a line perpendicular to } E F \text { at } \\
\text { point } F\end{array}$ \\
\hline 14 & Do Intersect & $\begin{array}{l}\text { - Select the shape Intersect } \\
\text { - Then, select segment } B C \text { and line } \\
\text { perpendicular to } E F \text { at point } F \text { to create the intersection } H\end{array}$ \\
\hline 15 & Segment & $\begin{array}{l}\text { - Select the shape Segment } \\
\text { - Then, choose } 2 \text { points } E, F \\
\text { - Then, choose } 2 \text { points } F, H \\
\text { - Then, choose } 2 \text { points } G, H\end{array}$ \\
\hline 16 & Dolygon & $\begin{array}{l}\text { - Select the shape Polygon } \\
\text { - Choose from point } E \text { to points } F, G, H \text {, and endpoint } E \text { to draw polygon } \\
E F H G\end{array}$ \\
\hline 17 & $\mathrm{~cm}^{2}$ Area & $\begin{array}{l}\text { - Select the shape Area } \\
\text { - Select the rectangle EFHG. Then the area of the rectangle is q1. }\end{array}$ \\
\hline 18 & $\begin{array}{l}\mathrm{O}=(0,0) \\
\text { Input... }\end{array}$ & Enter the command $O=(0,0)$ in the box Input \\
\hline 19 & (-) Circle: Center \& Radius & $\begin{array}{l}\text { - Select the shape Circle: Center \& Radius } \\
\text { - Then, select point } O \text { and enter radius } q 1 \text {. }\end{array}$ \\
\hline 20 & $\gamma_{q}$ Intersect & $\begin{array}{l}\text { - Select the shape Intersect } \\
\text { - Then, select the vertical axis and the circle c } \\
\text { - Right-click at the intersection and choose to rename the point as } J \text {. }\end{array}$ \\
\hline 21 & I Perpendicular Line & $\begin{array}{l}\text { - Select the shape Perpendicular Line } \\
\text { - Then, select the vertical axis and point } J \text { to draw a line perpendicular to the } \\
\text { vertical axis at point } J\end{array}$ \\
\hline 22 & Do Intersect & $\begin{array}{l}\text { - Select the shape Intersect } \\
\text { - Then, select the line } E G \text { and the line perpendicular to the vertical axis at } J \\
\text { - Right-click at the intersection and choose to rename the point as } K \text {. } \\
\text { - Then, select the line } E G \text { and the horizontal axis } \\
\text { - Right-click at the intersection and choose to rename the point as } L \text {. }\end{array}$ \\
\hline 23 & . Segment & $\begin{array}{l}\text { - Select the shape Segment } \\
\text { - Then, choose } 2 \text { points } K \text { and } L\end{array}$ \\
\hline 24 & - Show / Hide Object & $\begin{array}{l}\text { - Select the shape Show/Hide Object } \\
\text { - Then select the lines } E G, N F, F H, A D, J K \text {, and circle } c \text { and then select the } \\
\text { arrow-shaped movement icon in the toolbar. }\end{array}$ \\
\hline \multicolumn{3}{|c|}{ Step 3: Determine the properties and relationships as required by the problem } \\
\hline \multicolumn{2}{|c|}{$\begin{array}{l}\text { The locus of which point in the drawing is the value } \\
\text { q1 of the area of the rectangle } E F H G \text { ? } \\
\text { Please use the software to create a locus for point } K \\
\text { when moving point } E \text {. }\end{array}$} & $\begin{array}{l}\text { The value of } \mathrm{q} 1 \text { is the locus of the } \mathrm{K} \text { point in the drawing. } \\
\text { Students receive and implement. }\end{array}$ \\
\hline $\begin{array}{l}\text { Numerica } \\
1 \text { order }\end{array}$ & Shapes & Steps \\
\hline 25 & 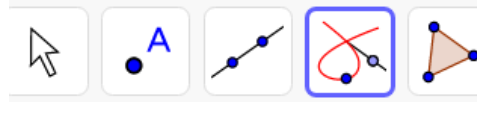 & $\begin{array}{l}\text { - Select the shape Locus } \\
\text { - Then choose point } \mathrm{K} \text { (the point to take the locus) and point } \mathrm{E} \text { (the moving } \\
\text { point). }\end{array}$ \\
\hline
\end{tabular}


Table 2 Continued

How are the results on the GeoGebra software screen displayed?

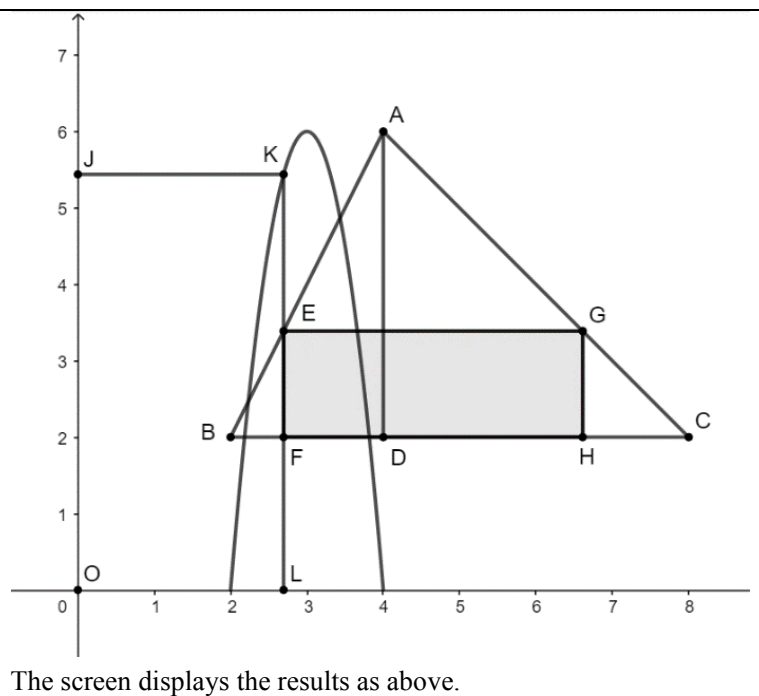

Observe the changing value of $\mathrm{q} 1$ as $E$ moves, realizing that the value $\mathrm{q}_{1}$ is largest when the point $K$ is at the highest position of the parabolic locus. Then, $E$ is the midpoint of segment $A B$. From there predict $\quad \frac{x}{a}=\frac{1}{2}$.

Or $E$ is the midpoint of $A B$ and $G$ is the midpoint of $A C$.
Move point $\mathrm{E}$, point $\mathrm{K}$ will move. Observe the locus of point $\mathrm{K}$ and comment that $\mathrm{q}_{1}$ reaches the maximum value at which position of point $E$ and then what is the ratio $\frac{E F}{A D}=\frac{x}{a}$ ?
Step 4: Solve the problem

From the predicted results in the software $\frac{x}{a}=\frac{1}{2}$, then what is the largest area of the rectangle EFHG $x y=\frac{b}{a}(a-x) x^{?}$

Can you give a detailed solution based on the predicted results of GeoGebra software?
The largest area of the rectangle EFHG $x y=\frac{b}{a}(a-x) x$ is $\frac{a b}{4}$ at $\frac{x}{a}=\frac{1}{2}$.

Suppose $E G=x, E F=y$.

$(0 \leq x \leq a, 0 \leq y \leq b)$

The area of the rectangle $E F H G$ is $x y$

Since $\triangle A E F " \triangle A B C$, so $\frac{y}{b}=\frac{a-x}{a} \Rightarrow y=\frac{b}{a}(a-x)$

Therefore, $x y=\frac{b}{a}(a-x) x$

Based on GeoGebra software, we predict the largest area of the rectangle EFHG $x y=\frac{b}{a}(a-x) x$ is $\frac{a b}{4}$ at $\frac{x}{a}=\frac{1}{2}$.

Indeed, we consider the following difference:

$\frac{b}{a}(a-x) x-\frac{a b}{4}=b x-\frac{b}{a} x^{2}-\frac{a b}{4}$

$=\frac{b}{a}\left(a x-x^{2}-\frac{a^{2}}{4}\right)$

$=-\frac{b}{a}\left(x-\frac{a}{2}\right)^{2} \leq 0$

Hence, the area of the rectangle EFHG $x y=\frac{b}{a}(a-x) x$ reaches its maximum value of $\frac{a b}{4}$ at $\frac{x}{a}=\frac{1}{2}$.

So the largest area of the rectangle EFHG is $\frac{a b}{4}=\frac{1}{2} S_{\triangle A B C}$ at $x=\frac{a}{2}, y=\frac{b}{2}$ 
Table 2 Continued

\begin{tabular}{|c|c|}
\hline \multicolumn{2}{|l|}{ Step 5: Create similar problems (if any) } \\
\hline $\begin{array}{l}\text { Please state the same problem or the extension problem } \\
\text { of Example 1? }\end{array}$ & $\begin{array}{l}\text { State the same problem: } \\
\text { Example } 2 \\
\text { Given an obtuse triangle } A B C \text { with the base side } B C=b \text { and altitude } A D=a \text {. Find } \\
\text { the dimensions of the rectangle so that the area of the rectangle is as large as } \\
\text { possible and inscribed within the triangle, knowing that one side of the rectangle } \\
\text { lies on the base } B C \text { as shown. }\end{array}$ \\
\hline Please prove this problem. & 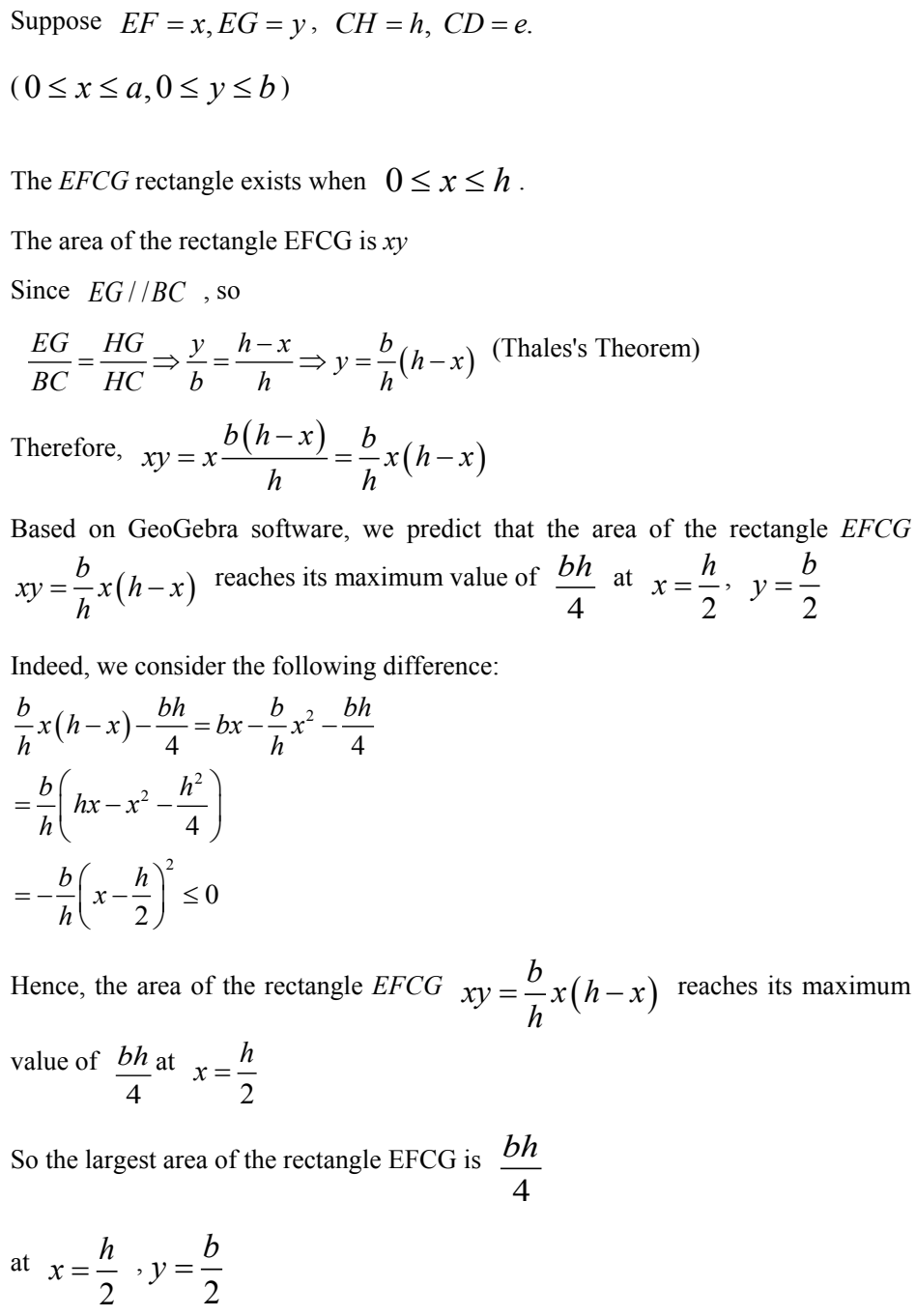 \\
\hline
\end{tabular}




\section{Discussion}

\subsection{Time and Experimental Subjects}

The pedagogical experiment was conducted at Mach Kiem Hung Secondary School (District 5, Ho Chi Minh City) according to the basic curriculum of the academic year 2020-2021.

- Experimental class 9A1 includes 44 students. Math Teacher: Ngo Nhut Tai.

- Control class 9A7 includes 43 students. Math Teacher: Ngo Nhut Tai.

We design lesson plans and implement teaching content "Practice exercises in chapter III" for both classes. For the experimental class, the teacher will teach according to the lesson plan of discovery teaching about the plane geometry extreme math problem with the help of GeoGebra software. For the control class, the teacher will teach according to the program distribution. Plane geometry problems must satisfy the following contents:

- Define clearly key knowledge, skills to be achieved.

- Appropriate in terms of time and general knowledge of students.

- Activities in the teaching process must help students foster the ability to use mathematical tools and means through teaching plane geometric extreme problems with the support of GeoGebra software.

\subsection{Process of Pedagogical Experiment}

- Investigate and evaluate the learning situation of students in experimental and control classes.

- Prepare documents, compile experimental lesson plans.

- Teachers teach according to the compiled lesson plan.

- After the teaching is completed, the teacher proceeds to let the experimental class and the control class do the 45-minute test (missing test)
- Collect, analyze and evaluate test results of experimental and control classes.

\subsection{Methods of Experimental Evaluation}

We use the following experimental evaluation methods:

- Classroom observations: to receive students' feedback on lessons about excitement, positive attitude, cognitive level, and applicability.

- Interview: we use the method of interviewing by talking to students to clarify information about the interest level of measures that are difficult to determine through observation. We interview teachers to know about the teachers 'evaluation and comments on students' excitement and perception level in the experiment.

- Essay test: aims to assess students' ability to comprehend knowledge through the lesson and test individual knowledge of experimental and control classes through an essay test after the experiment. The content of the test is based on the lesson plan's goal and pays special attention to exercises to evaluate the effectiveness of using GeoGebra software in plane geometry problems. Scores of the tests are scored on a scale of 10 .

\subsection{Experimental Analysis}

\subsubsection{Analyzing before the experiment}

We interviewed the homeroom teacher and the math teacher of the two classes in the previous school year and received comments that the two classes have similar performances.

\section{* Students:}

The two groups selected to participate in the research have many similarities in academic performance and learning ability as follows:

Table 3. Academic performance of grade 9A1 and grade 9A7 students of Mach Kiem Hung Secondary School

\begin{tabular}{|c|c|c|c|c|c|c|c|}
\hline & \multicolumn{4}{|c|}{ The number of students in groups } & \multicolumn{4}{c|}{ Academic performance } \\
\hline & Total & Male & Female & Good & Fair & Average & Poor \\
\hline Grade 9A1 & 44 & 23 & 21 & 14 & 20 & 10 & 0 \\
\hline Grade 9A7 & 43 & 22 & 21 & 16 & 18 & 9 & 0 \\
\hline
\end{tabular}


In terms of learning sense, all students in these two groups are active.

In terms of academic performance for the previous school year, the two groups are similar in math scores.

- The mean of math scores for the previous school year of the experimental class is 7.13 points.

- The mean of math scores for the previous school year of the control class is 7.17 points.

\subsubsection{Analyzing experimental results}

a) Qualitative assessment

We conducted experimental teaching while following up, observing the progress, and interviewing to give some comments as follows:

- Before experimenting, students in both classes had not had much access to GeoGebra software as well as used Geogebra software in solving plane geometric extreme problems, so although students were interested in it, students were still hesitant and did not know how to apply the software to solving geometry problems.

- During the experiment, we commented on the process in following table.

Thus, compared to the control class, students in the experimental class not only can apply information technology to mathematics, manipulate and observe the movement of objects as well as see the dynamic model of mathematics but also know how to use software to predict the results of the problem. On that basis, they give a more accurate and confident solution, increase students' ability to acquire knowledge, and slowly overcome obstacles in learning geometry.

\begin{tabular}{|c|c|}
\hline Session & xpression \\
\hline $\begin{array}{l}\text { Session 1: Introduce the GeoGebra software } \\
\text { and instruct students to draw some simple } \\
\text { figures on GeoGebra software. }\end{array}$ & $\begin{array}{l}\text { - Although students are interested, they are still shy. } \\
\text { - When drawing a shape, they are confused, unable to fully imagine the steps to draw a } \\
\text { figure } \\
\text { - Only } 1 \text { or } 2 \text { students can draw perfect and precise figures as required by the problem. }\end{array}$ \\
\hline $\begin{array}{l}\text { Session 2: Students practice drawing on the } \\
\text { software and comment on the relationships of } \\
\text { objects. }\end{array}$ & $\begin{array}{l}\text { - Students start to actively ask teachers when they have questions and are excited to } \\
\text { draw figures on the software } \\
\text { - The number of students practicing drawing figures proficiently is more. } \\
\text { - Faster drawing operations } \\
\text { - The whole class is active and enthusiastic to emulate and manipulate the software. } \\
\text { - Some students also practice with the software at home and write down questions, then } \\
\text { ask the teacher in the next class. }\end{array}$ \\
\hline $\begin{array}{l}\text { Session 3: Students draw figures and then start } \\
\text { to predict the results of the problem. (Studying } \\
\text { in the computer room) }\end{array}$ & $\begin{array}{l}\text { - Students quickly draw figures of math problems on GeoGebra software with } \\
\text { computers and are curious about how to predict the results of GeoGebra software. } \\
\text { - When listening to the teacher suggesting ways to predict the results, most students sit } \\
\text { quietly and have not yet figured out how to do it. } \\
\text { - After students practice following the manipulations, they begin to enjoy making } \\
\text { predictions. } \\
\text { - Although the predictions are wrong and sometimes spontaneous, the students have } \\
\text { boldly stated and expressed their prediction thinking, not as shy as the first time. }\end{array}$ \\
\hline $\begin{array}{l}\text { Session 4: Teachers create similar lessons and } \\
\text { let students draw figures and make predictions } \\
\text { on the software (Computer room). }\end{array}$ & $\begin{array}{l}\text { - Students receive ideas, draw figures and start the prediction process. } \\
\text { - Students are excited to present their prediction and prediction results with more basis } \\
\text { and accuracy. From the prediction results of the software, students gave the correct } \\
\text { solution. }\end{array}$ \\
\hline
\end{tabular}

Table 4. Table of the frequency distribution of test scores of experimental class (Expr) and control class (Ctrl) (after the experiment)

\begin{tabular}{|c|c|c|c|c|c|c|c|c|c|c|c|c|}
\hline & \multicolumn{10}{|c|}{ Scores } & \multirow{2}{*}{ Total } \\
\hline & & 5,5 & 6,0 & 6,5 & 7,0 & 7,5 & 8,0 & 8,5 & 9,0 & 9,5 & 10,0 & \\
\hline \multirow{2}{*}{ Class } & Expr & 0 & 3 & 1 & 7 & 6 & 10 & 6 & 5 & 4 & 2 & 44 \\
\hline & $\mathrm{Ctrl}$ & 4 & 6 & 5 & 5 & 3 & 8 & 2 & 6 & 3 & 1 & 43 \\
\hline \multicolumn{2}{|c|}{ Total } & 4 & 9 & 6 & 12 & 9 & 18 & 8 & 11 & 7 & 3 & 87 \\
\hline
\end{tabular}


b) Quantitative assessment

We gave students in the experimental and control classes a 45-minute test. We conduct a quantitative analysis based on the test results. First of all, we create table 4 as above.

From the data in table 4, we have chart 2 to compare the scores of the two classes:

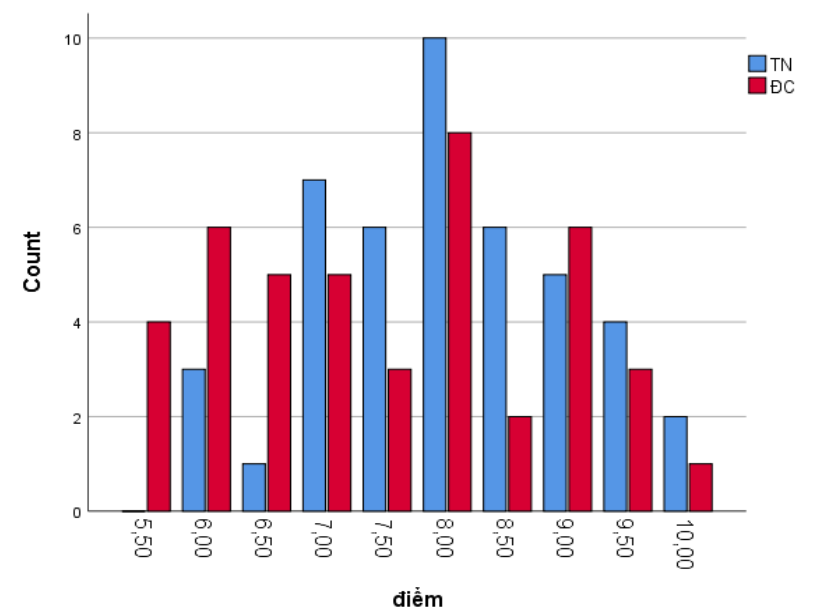

Figure 4. Column chart comparing test scores of experimental and control classes (after the experiment)

Looking at chart 2, we can see that the height of the point columns and the distribution of points of the two classes have differences. The scores of the experimental class are 6-10 points or more and most are 7-9 points. The distribution of scores of the control class is from 5.5 to 10 points and 6-9 points account for a large number of points.

Besides, we also obtain the following statistics characteristic parameters:

Table 5. Table of characteristic parameters of the statistics on experimental and control class (post-experimental) test scores in SPSS

\begin{tabular}{|c|c|c|c|c|}
\hline \multicolumn{2}{|c|}{} & \multicolumn{3}{|c|}{ Scores } \\
\cline { 3 - 5 } \multicolumn{2}{|c|}{} & Mean & Standard Deviation & Variance \\
\hline \multirow{3}{*}{ Class } & Expr & 8,01 & 1,04 & 1,08 \\
\cline { 2 - 5 } & Ctrl & 7,48 & 1,30 & 1,70 \\
\hline
\end{tabular}

Reading the above test result data, we have:

The mean of the test scores for the two classes is: $\overline{X_{T N}}=8,01 ; \overline{X_{D C}}=7,48$.

Variance: $S_{T N}^{2}=1,08 ; S_{D C}^{2}=1,70$

Comment: the mean and variance of the two classes have a big difference. The mean of the experimental class is higher; The standard deviation and variance are lower, so the concentration around the mean is higher than that of the control. We can say that the experimental class's score is higher than that of the control class.

To accurately assess the high and low between the average scores of the two experimental classes, we test the average between the two classes, with a significance level of $\alpha=0,05$ through Table 6 with two assumptions:

Hypothesis

$H_{0}$ : "The average scores of the experimental class and the control class are similar".

$H_{1}$ : "The average score of the experimental class is higher than that of the control class".

From the result table, we have:

Levene test has a value of $\operatorname{Sig}=0$, so the variance of two classes is different, using Independent-samples T-test results corresponding to equal variances not assumed.

- With the Independent-samples T-test test, we have Sig. $(2$-tailed $)=0,038<\alpha=0,05$, which should reject hypothesis $H_{0}$, accept hypothesis $H_{l}$. So the average score of the experimental class is $5 \%$ higher than that of the control class.

- By the method of testing between classes with equivalent performance, the results show that the experimental class, after being taught according to the experimental lesson plan, the test has better results, the average score is higher than the control class. It can be seen that the application process for the experimental class is feasible and effective in teaching.

Table 6. Average T-test checklist of test scores of experimental and control classes (post-experimental) in SPSS

\begin{tabular}{|c|c|c|c|c|c|c|c|c|c|c|}
\hline \multicolumn{11}{|c|}{ Independent Samples Test } \\
\hline & & \multicolumn{2}{|c|}{$\begin{array}{c}\text { Levene's Test for } \\
\text { Equality of Variances }\end{array}$} & \multicolumn{7}{|c|}{ t-test for Equality of Means } \\
\hline & & \multirow[t]{2}{*}{$\mathrm{F}$} & \multirow{2}{*}{ Sig. } & \multirow[t]{2}{*}{$\mathrm{t}$} & \multirow{2}{*}{ df } & \multirow{2}{*}{$\begin{array}{c}\text { Sig. } \\
\text { (2-tailed) }\end{array}$} & \multirow{2}{*}{$\begin{array}{c}\text { Mean } \\
\text { Difference }\end{array}$} & \multirow{2}{*}{$\begin{array}{l}\text { Std. Error } \\
\text { Difference }\end{array}$} & \multicolumn{2}{|c|}{$\begin{array}{c}95 \% \text { Confidence Interval } \\
\text { of the Difference }\end{array}$} \\
\hline & & & & & & & & & Lower & Upper \\
\hline \multirow[b]{2}{*}{ Scores } & $\begin{array}{c}\text { Equal } \\
\text { variances } \\
\text { assumed }\end{array}$ & 5,004 & 0,028 & 2,118 & 85 & 0,037 & 0,53462 & 0,25236 & 0,03286 & 1,03637 \\
\hline & $\begin{array}{c}\text { Equal } \\
\text { variances not } \\
\text { assumed }\end{array}$ & & & 2,113 & 80,068 & 0,038 & 0,53462 & 0,25302 & 0,03110 & 1,03814 \\
\hline
\end{tabular}




\section{Conclusions}

Discovery teaching is an active teaching method. This teaching method is effective in math problems that is applied by teaching software in general and GeoGebra software in particular. In particular, for plane geometric extreme problems, GeoGebra software brings into full play its available potential. The article has gone into depth to solve the three questions posed in the research process. That is, the view of discovery teaching, teaching process to discover plane geometric extreme problems with the help of GeoGebra software and an example illustrating discovery teaching of extreme math problems of plane geometry with the help of GeoGebra software. In addition, by practical experiments, the article has also shown the progress of students in the experimental class through each teaching period. Students have been proactive and enthusiastic in answering questions as well as having more active activities in building lessons. Students can solve problems of plane geometry by themselves, have more confidence in their ability to use mathematical tools and means with the help of GeoGebra software. Finally, the article also shows that the application process for the experimental class is completely feasible and highly effective in teaching.

\section{Acknowledgments}

We are very grateful to Nguyen Viet Duong for reading and improving this article.

\section{REFERENCES}

[1] W. Van Joolingen, "Cognitive Tools for Learning," Int. J. Artif. Intell. Educ., vol. 10, pp. 385-397, 1999, doi: 10.1007/978-3-642-77222-1.

[2] D. Ardianto and B. Rubini, "Comparison of students' scientific literacy in integrated science learning through model of guided discovery and problem based learning," $J$. Pendidik. IPA Indones., vol. 5, no. 1, pp. 31-37, 2016, doi: 10.15294/jpii.v5i1.5786.

[3] W. S. Adeliaa and E. Surya, "Resolution to Increase Capacity by using Math Students Learning Guided Discovery Learning (gdl)," Int. J. Sci. Basic Appl. Res., vol. 34, no. 1, pp. 144-154, 2017, [Online]. Available: https://scholar.google.c o.id/scholar?hl=id\&as_sdt $=0 \% 2 \mathrm{C} 5 \& \mathrm{q}=$ Resolution+to+Incre ase + Capacity + by + using + Math + Students + Learning + Guided + Discovery+Learning $+\% 28 \mathrm{gdl} \% 29 \& \mathrm{btnG}=$.

[4] M. D. Svinicki, "A theoretical foundation for discovery learning," Am. J. Physiol., vol. 20, no. 1, pp. 4-7, 1998, doi: 10.1152/advances.1998.275.6.s4.

[5] T. De Jong and W. R. Van Joolingen, "Scientific discovery learning with computer simulations of conceptual domains,"
Rev. Educ. Res., vol. 68, no. 2, pp. 179-201, 1998, doi: $10.3102 / 00346543068002179$.

[6] J. A. Castronova, "Discovery learning for the 21 st century: What is it and how does it compare to traditional learning in effectiveness in the 21st century?," Action Res. Exch., vol. 1, no. 1, pp. 1-12, 2002.

[7] D. Lyu and B. Wang, "Effects of the application of computer network technology to guided discovery teaching on learning achievement and outcome," Eurasia J. Math. Sci. Technol. Educ., vol. 14, no. 7, pp. 3269-3276, 2018, doi: 10.29333/ejmste/91249.

[8] D. Hammer, "Discovery learning and discovery teaching," Cogn. Instr., vol. 15 , no. 4, pp. 485-529, 1997, doi: 10.1207/s1532690xci1504_2.

[9] M. A. McDaniel and M. S. Schlager, "Discovery Learning and Transfer of Problem-Solving Skills," Cogn. Instr., vol. 7, no. 2, pp. 129-159, 1990, doi: 10.1207/s1532690xci0702_3.

[10] L. Alfieri, P. J. Brooks, N. J. Aldrich, and H. R. Tenenbaum, "Does Discovery-Based Instruction Enhance Learning?," J. Educ. Psychol., vol. 103, no. 1, pp. 1-18, 2011, doi: 10.1037/a0021017.

[11]D. J. Reid, J. Zhang, and Q. Chen, "Supporting scientific discovery learning in a simulation environment," J. Comput. Assist. Learn., vol. 19, pp. 9-20, 2003.

[12] N. J. Anastasiow, S. A. Sibley, T. M. Leonhardt, and G. D. Borich, "A Comparison of Guided Discovery, Discovery and Didactic Teaching of Math to Kindergarten Poverty Children," Am. Educ. Res. J., vol. 7, no. 4, pp. 493-510, 1970, doi: 10.3102/00028312007004493.

[13] Y. Zengin, H. Furkan, and T. Kutluca, "The effect of dynamic mathematics software geogebra on student achievement in teaching of trigonometry," Procedia - Soc. Behav. Sci., vol. 31, no. 2011, pp. 183-187, 2012, doi: 10.1016/j.sbspro.2011.12.038.

[14] P. Sari, A. Hadiyan, and D. Antari, "Exploring Derivatives by Means of GeoGebra," Int. J. Emerg. Math. Educ., vol. 2, no. 1, pp. 65-78, 2018, doi: 10.12928/ijeme.v2i1.8670.

[15] T. Kutluca, "The effect of geometry instruction with dynamic geometry software; GeoGebra on Van Hiele geometry understanding levels of students," Glob. Educ. J. Sci. Technol., vol. 8, no. 17, pp. 1509-1518, 2013, doi: 10.5897/ERR2013.1554.

[16] T. H. Nguyen and T. A. Le, "Exploiting the GeoGebra software in some situations of learning Mathematics Grade 9th," Vietnamese Educ. journal, Spec. number 6/2018, pp. 163-167, 2018.

[17] D. Majerek, "Application of Geogebra for Teaching Mathematics," Adv. Sci. Technol. Res. J., vol. 8, no. 24, pp. 51-54, 2014, doi: 10.12913/22998624/567.

[18] M. D. Bui, "Using the Geogebra software to aid the teaching of solving solid geometric problems by the tactics 'spreading figure," Vietnamese Educ. J. Spec. Number (Avril 3/2017), pp. 122-125, 2017.

[19] Y. A. Wassie and G. A. Zergaw, "Some of the potential affordances, challenges and limitations of using GeoGebra in mathematics education," Eurasia J. Math. Sci. Technol. Educ., vol. 15, no. 8, 2019, doi: 10.29333/ejmste/108436. 
[20] L. Dikovic, "Implementing dynamic mathematics resources with geogebra at the college level," Int. J. Emerg. Technol. Learn., vol. 4, no. 3, pp. 51-54, 2009, doi: 10.3991/ijet.v4i3.784.

[21] A. Escuder and J. M. Furner, "The Impact of GeoGebra in Math Teacher's Professional Development," Int. Conf. Technol. Coll. Math., pp. 76-84, 2011.

[22] J. Hohenwarter, M., Hohenwarter, "Teaching and Learning Calculus with Free Dynamic Ma- thematics Software GeoGebra Calculus with GeoGebra," in Proceedings of the International Conference on the Teaching of Mathematics TSG 16, September 2016, pp. 1-9.

[23] B. Mainali and M. Key, "Using Dynamic Geometry Software GeoGebra in Developing Countries: A Case Study of Impressions of Mathematics Teachers in Nepal.," Int. J. Math. ..., no. February, pp. 1-16, 2012, [Online]. Available: http://www.cimt.plymouth.ac.uk/Journal/mainali.pdf.

[24] G. Aldon and J. Trgalov, "A CASE STUDY OF A SECONDARY MATHEMATICS TEACHER , S CLASSROOM PRACTICE WITH WEB-BASED DYNAMIC MATHEMATICAL SOFTWARE Proceedings of the 13th International Conference on Technology in
Mathematics Teaching ICTMT 13 Ecole Normale Sup ' erieure de Lyon / Unive,” 2017.

[25] T. N. Nguyen, "Potential and Advantatages of dynamic geometry software Cabri in teaching and learning Mathematics: the case of teaching the notion of function," $J$. Sci. HNUE, vol. 61, no. 6, pp. 60-68, 2016, doi: 10.18173/2354-1075.2016-0049.

[26] V. L. Nguyen, "The Learning of proving theorems on transformations with the help of learning software," Vietnamese Educ. J., vol. 1-4/2011, no. 259, pp. 46-48, 2011.

[27] V. M. T. Le and P. L. Nguyen, "SPWG: The model of solving peroblems with the Geogebra dynamic geometric software," Vietnamese Educ. J., vol. 1-3/2015, no. 353, pp. 45-47, 2015.

[28]D. H. Nguyen, "Teaching geometry theorems using Geospace software," J. Sci. HNUE, vol. 60, no. 8A, pp. 144151, 2015, doi: 10.18173/2354-1075.2015-0175.

[29] N. G. Nguyen, "Discovering locus problems with the help of the Cabri software," Vietnamese Educ. J., vol. 2-8/2013, no. 316, pp. 52-54, 2013. 